\title{
II. DOCUMENTOS
}

\section{ACOTACIONES SOBRE ORIGINALES DE PABLO NERUDA}

\author{
Nurieldín Hermosilla Rumié \\ nurieldin@hermosillaabogados.cl
}

Tratándose de libros viejos y de poesía, la materialidad y las formas ayudan notablemente a la comprensión a través del impacto visual y del arte del diseño (tanto material como en la estrofa misma). Para el bibliófilo, así como para el comentarista y el crítico, asumen importancia preponderante. En ese terreno, Pablo Neruda fue un verdadero virtuoso, no solo por el interés que siempre puso en el diseño y en la impresión de cada una de sus obras, sino también por el arte de ingenio, de humor y de afectos que desplegó en las dedicatorias, mensajes y regalos que hacía en particular a sus amadas y a sus amigos. Para un coleccionista, que quiere reconstituir el pasado a través de sus obras, tanto materiales como literarias, son tan importantes sus pequeños dibujos, como las largas copias manuscritas de sus propios poemas y algunos collages o dibujos de diferentes tamaños. El coleccionista también busca recomponer el ambiente familiar o de amigos, de sus visitas y viajes, en una palabra, el contexto de lecturas, paisajes y personas que lo rodearon en sus diferentes épocas a través, precisamente, de estas mismas ediciones, manuscritos, cartas, recados y fotografías.

Sin propensión al goce únicamente privado de mi colección nerudiana, en algunas ocasiones he facilitado un número considerable de piezas más o menos importantes para compartirlas con el público que, por ejemplo, frecuentó la exposición en Codelco, julio del 2004, durante el centenario del poeta. Aquí me interesa solo transmitir mediante imágenes y comentarios lo que acabo de explicar: son páginas sueltas de libros escritos por Neruda; son recados, dedicatorias, manuscritos y algunos poemas "escritos directamente a la máquina”, como él dice, pero que traen además las primeras correcciones efectuadas por la mano misma del que muchos consideran el más importante poeta del siglo XX. En orden cronológico, incluiré impresos y documentos, y también fotografías que hablan por sí solas (salvo datos del contexto histórico), todo material inédito y desconocido, no estudiado ni revisado críticamente, elementos muy ligados a su vida de amistad y/o

${ }^{1}$ Abogado, bibliófilo, coleccionista y nerudiano. 
a antiguos amores de la juventud, a veces contemporáneos. Eran regalos hechos de su propia mano a uno de sus amigos desde la infancia en Temuco; otros a su amada de la boina gris y a su probable sucesora o, a lo mejor, su casi contemporánea amiga.

\section{EL POEMA DOS DE LOS VEINTE POEMAS DE AMOR Y UNA CANCIÓN DESESPERADA}

Comienzo por presentar lo que estimo tres versiones distintas para el Poema Dos de los Veinte Poemas de Amor y una Canción Desesperada, a través de siete fotografías²: las numeradas 1 a 5 corresponden a cinco páginas de un muy especial ejemplar de la primera edición del libro (Santiago, Nascimento, 1924), y las numeradas 6 y 7 a dos páginas de la segunda edición (Santiago, Nascimento, 1932).

Foto $\mathrm{n}^{\circ}$ 1. Dedicatoria manuscrita por Neruda al amigo poeta Ángel Cruchaga Santa María y a Albertina Azócar, su cónyuge, quien fuera la muchacha de la boina gris: Para / Ángel y / Albertina / este libro lleno / de recuerdos y de / olvidos (30 años después) / Pablo / Neruda / 1954.

Foto $\mathrm{n}^{\mathrm{o}} 2$. Portadilla del volumen y en la página de enfrente una nueva dedicatoria, sin fecha pero muy adornada con guirnaldas de flores, alguna flecha curvada, un pez, gaviotas, todas figuras típicas que usaba Pablo: Para Ángel y Albertina. Isla Negra. Pablo Neruda. Foto $\mathrm{n}^{\mathrm{o}}$ 3. Bajo el subtítulo los veinte poemas, así en minúsculas, Neruda manuscribió: En tus ojos de luto / comienza el país / del sueño / Pablo, citando el último verso del poema 16.

Fotos $\mathrm{n}^{\mathrm{o}} 4 \mathrm{y} \mathrm{n}^{\mathrm{o}} 5$. Traen el poema 2 con anotaciones manuscritas al margen, las que corresponden a términos o fragmentos de la versión definitiva del poema 2 en la segunda edición (1932).

Fotos $n^{\circ} 6$ y n $n^{\circ}$. Versión del poema 2 en la edición 1932.

${ }^{2}$ Fotografías: Lily Robres. 


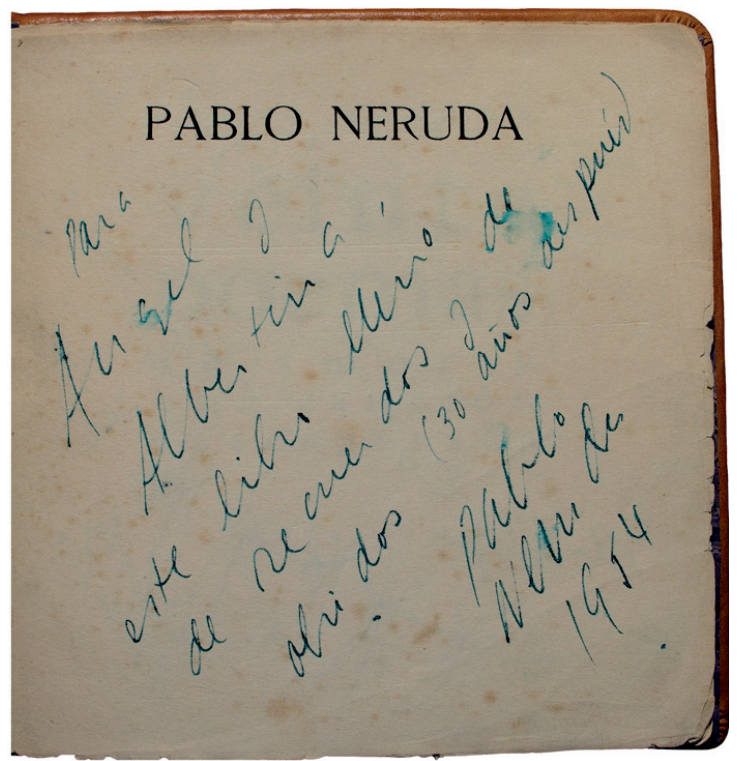

Foto 1

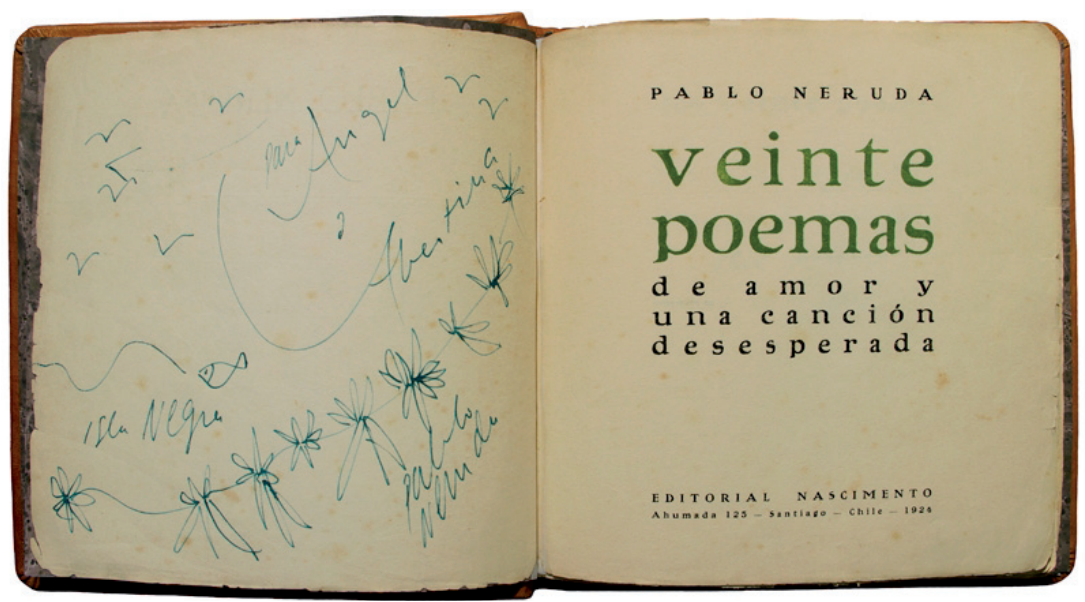

Foto 2 


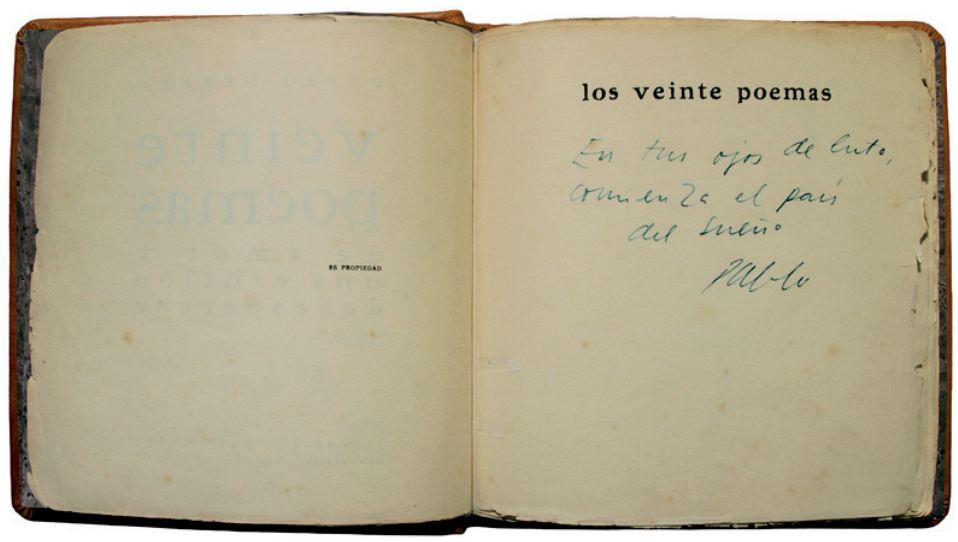

Foto 3

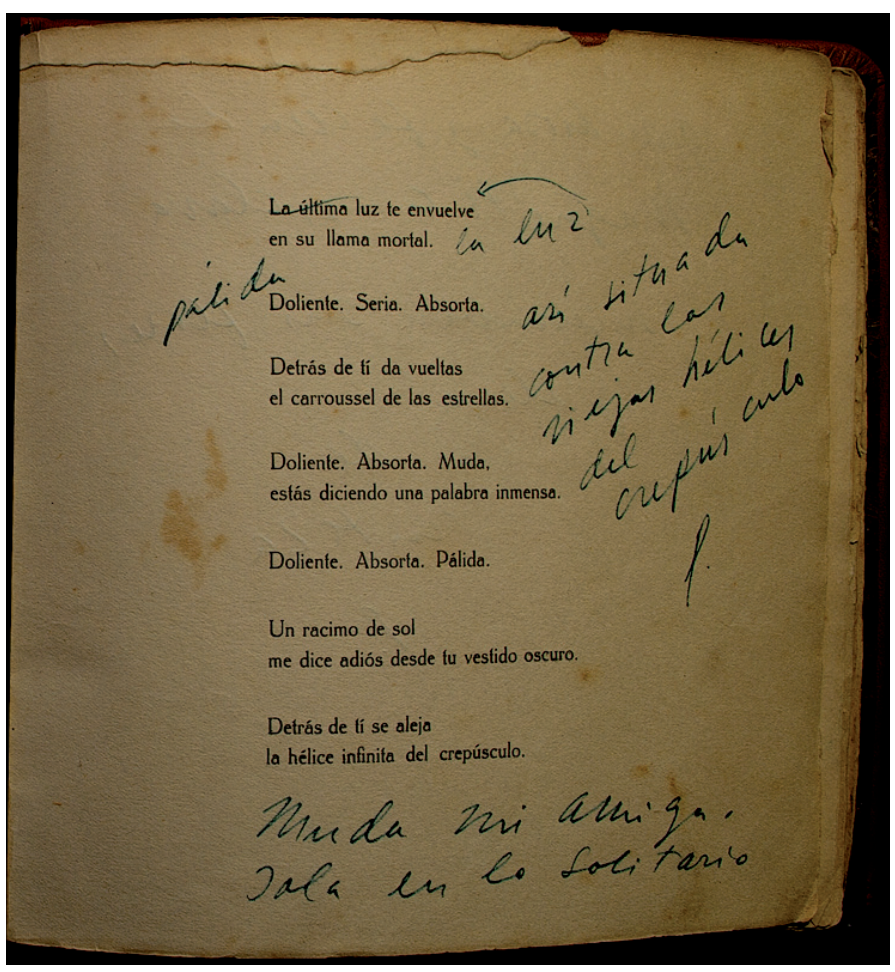

Foto 4 


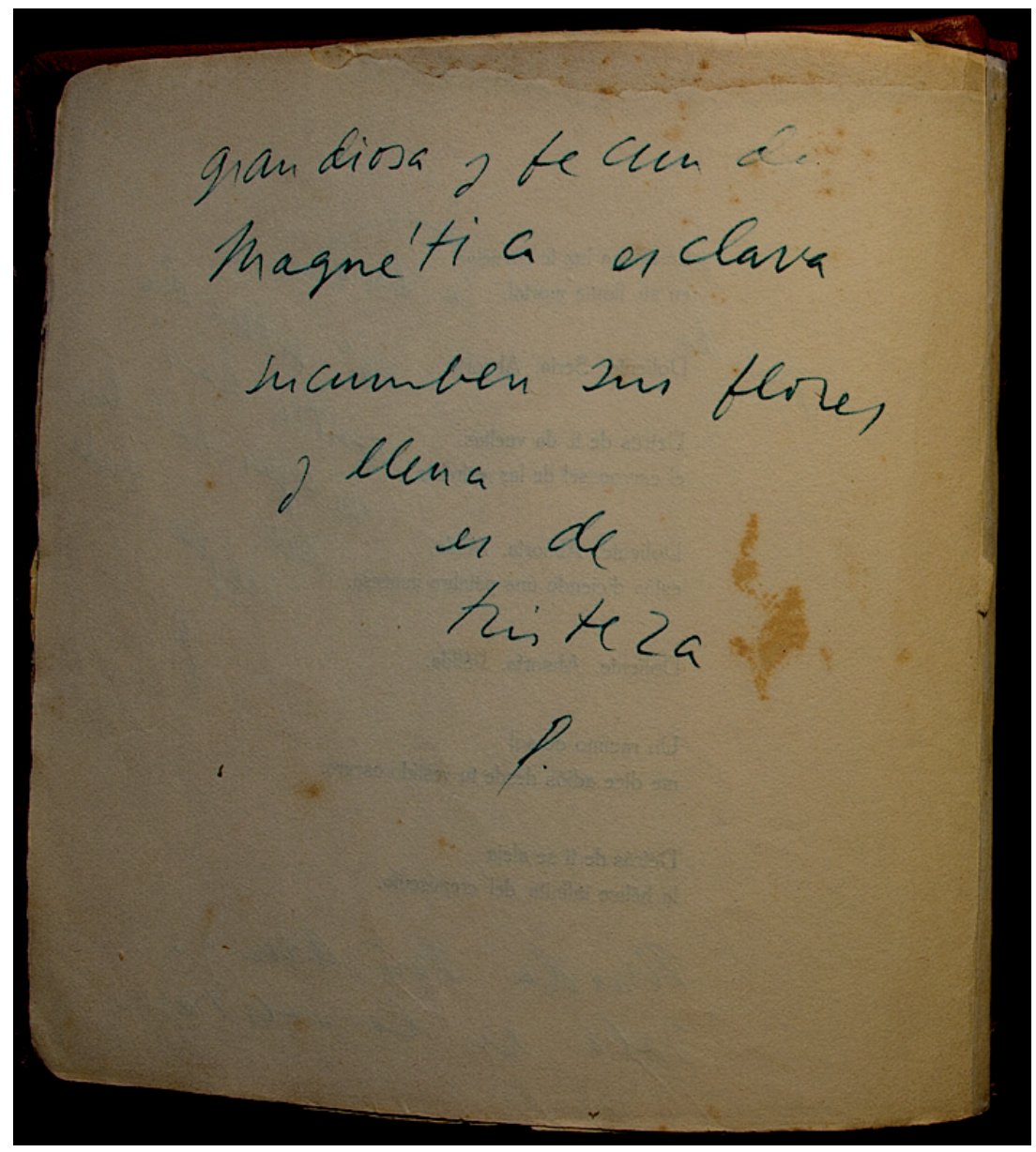

Foto 5 


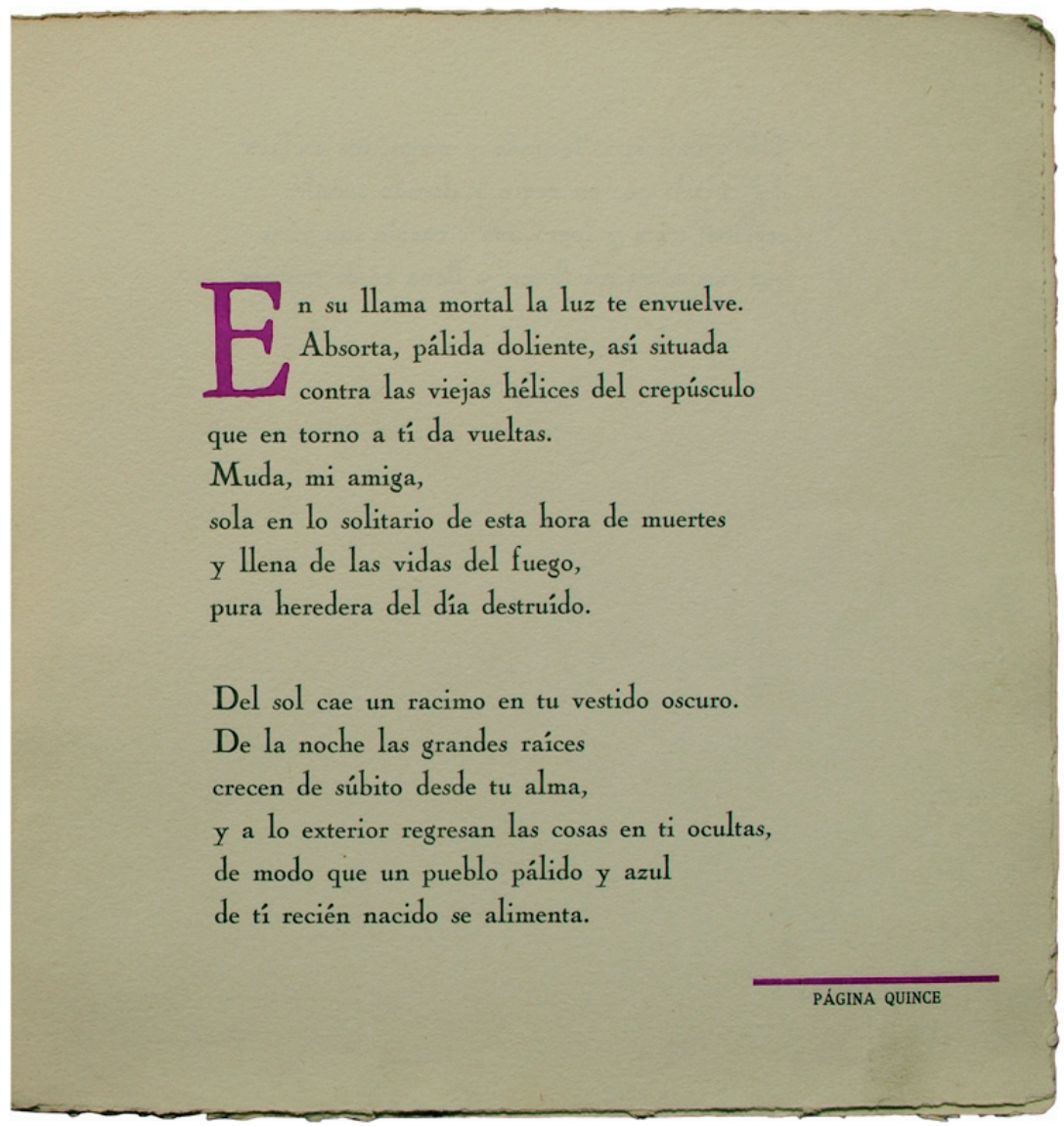

Foto 6 
Oh grandiosa y fecunda y magnética esclava del ćrculo que en negro y dorado sucede: erguida, trata y logra una creación tan viva que sucumben sus flores, y llena es de tristeza.

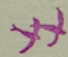

PÁGINA DIECISÉIS

\section{Foto 7}


Mi interpretación, discutida y no concordada con Hernán Loyola, en nuestras discusiones vía skype, él desde Sassari, Cerdeña, a la hora en que ya no suenan los teléfonos, es la siguiente:

Mi tesis es que resultan tres versiones distintas del Poema Dos, que se colocan en paralelo en la página siguiente. Las grandes diferencias están entre el poema primero y las otras dos versiones. Éste es un hallazgo, cuya significación corresponde hacerla a los estudiosos de Neruda. Puede que no tenga ninguna significación importante, pero -según Robert PringMill- él era un perseguidor tenaz incluso de las correcciones primeras, porque el verdadero significado del poema necesitaba de las versiones originarias y que cada poema contenía conceptos que a veces se expresaban en uno o dos versos, los que a su vez, contenían una o dos palabras que le daban movimiento, formas de acción, a veces el sentido transitivo de un verbo, la clave (en comentario hecho revisando El Gran Océano en su versión original, que va a continuación). Los bibliófilos no somos filólogos ni críticos literarios (aunque algunos lo sean o crean serlo), aunque tengamos callada opinión. Mi tesis o, más bien, mi idea es que estas tres versiones son superpuestas. El texto de 1924 corresponde al período 1920-1923. El texto manuscrito sobre la edición de 1924 debiera corresponder al período 1924-1932; pero, hay opiniones de que la tinta verde no la usó Neruda antes de 1932, sino que usaba solo tinta azul, negra o roja y, en algunos textos muy raros, lápiz grafito. Sin embargo, en el libro "para Albertina Rosa", hermosa edición en parte facsimilar, de gran empaste, editado por Francisco Cruchaga Azócar, Q.E.P.D., hijo de Albertina Rosa, Santiago, enero 1992, Editorial South PacificPress, página 279, está la famosa carta que le escribió Neruda en que explica precisamente por qué le contesta con tinta verde. Dice: "Tu hermosa carta color lila merece esta tinta color ala de caturra" (para los extranjeros: "caturra" es un pájaro pequeño de fuertes colores verdes, "del género Loro", de la familia "Caturras"). Por otros antecedentes (ver "Neruda Joven”, del Banco Exterior de España, Madrid, 1983, p. 36), que sitúa la carta los primeros meses de 1924, pues expone que está "arreglando los originales de "Veinte Poemas de Amor y una Canción Desesperada" que se editó en junio de 1924. Por consiguiente, antes de 1932 usaba también la tinta verde, y la roja y la azul y la negra. Y, por tanto, la corrección original sobre el texto de 1924 debió escribirse antes de 1932 y, naturalmente, no en 1954 cuando se estampó la última dedicatoria. Corrigió, aumentando el texto, entre 1924 y 1927, y cuando entregó el original para la publicación de la segunda edición de 1932, de vuelta de su viaje al Oriente, casi no corrigió, sino reacondicionó el texto para esa versión definitiva. Me parece, entonces, que hubo tres textos distintos, que son textos superpuestos, que fueron crecedores y con un mayor sentido poético que el original de la primera edición.

Cuando le dedica el libro a Ángel y a Albertina, puede ser que Pablo haya tratado de reproducir de memoria las modificaciones que aparecen en la edición del 32 y, en consecuencia, haberse escrito sin tener el ejemplar de 1932 a la vista y por eso resultó una versión distinta, aunque semejante. Neruda confeccionaba estos regalos sin pretensión poética. Eran figuras lúdicas, sin abandonar el sentido poético. Naturalmente que el ejemplar de 1924 se trataba de un regalo muy especial, nada menos que a la inspiradora de parte importante de sus poemas. Las anotaciones hechas directamente en el texto de 1924 fueron también modificadas al hacerse la corrección para la publicación del año 32 
y no cambia el hecho de encontrarnos con tres textos distintos, todos de Pablo Neruda, y que el texto definitivo es el publicado el año 1932.

En cuanto a las dedicatorias, pareciera que es una sola, aunque escritas en dos páginas distintas, y en 1954. En la dedicatoria fechada (1954) hay un mensaje interior de amargura y de reproche "este libro lleno de recuerdos y de olvidos (30 años después)", que coincide con el tono poético de la página subsiguiente a la portadilla, "en tus ojos de luto comienza el país del sueño". Pareciera que esta última hubiera sido la dedicatoria del libro original que Neruda le regaló a Albertina en los mismos años de su primera edición, cuando ella estaba soltera todavía. Escondió el apellido, pero, además, no habían ocurrido todavía los tácitos rechazos de Albertina mientras Neruda estaba en el Oriente (los "olvidos"). En cambio, en la dedicatoria de 1954 y en la que está dibujada, escrita y firmada, que a simple vista es como la continuación alegre de la del reverso, la tinta usada es distinta, así como las letras y la composición también son diferentes. La corrección del Poema Dos que viene en las páginas siguientes, confirma el estado de ánimo que Neruda tenía respecto de Albertina, que no es el mismo estado de ánimo de 1954. Albertina tampoco es aquélla que describe el Poema Dos y los rasgos además se acentúan con las modificaciones introducidas en la primera corrección puesta en el texto mismo. Imaginándome la escena y si esta corrección se hubiera hecho en 1924-1927, en algún encuentro de Neruda con Albertina, en un momento de reclamo amoroso, incluso, a lo mejor, estando juntos, Neruda modifica este poema, transformando la imagen de la amada, que no le contesta, sea desde Concepción o desde Europa sus reclamos. Es una imagen fría, casi estatuaria ("Oh grandiosa y fecunda y magnética esclava / del círculo que en negro y dorado sucede”).

En página siguiente cuadro comparativo resume mi tesis. 


\begin{tabular}{|c|c|}
\hline $\begin{array}{l}\text { Poema 2, Veinte Poemas de Amor y una Canción } \\
\text { Desesperada, Nascimento, } 1^{\mathrm{a}} \text { Edición, } 1924\end{array}$ & $\begin{array}{l}\text { Poema } 2 \text { con anotaciones manuscritas de Pablo Neruda en tinta verde } \\
\text { (Nascimento, } 1^{\mathrm{a}} \text { Edición, 1924) }\end{array}$ \\
\hline La última luz te envuelve & taúluz te envuelve \\
\hline En su llama mortal & $\begin{array}{l}\text { En su llama mortal la luz } \\
\text { pálida }\end{array}$ \\
\hline Doliente. Seria. Absorta & $\begin{array}{l}\text { Doliente. Seria. Absorta asi situada } \\
\text { contra las }\end{array}$ \\
\hline Detrás de ti da vueltas & Detrás de ti da vueltas viejashélices \\
\hline El carroussel de las estrellas. & $\begin{array}{l}\text { El carroussel de las estrellas det } \\
\text { crepúsculo }\end{array}$ \\
\hline Doliente. Absorta. Muda, & Doliente. Absorta. Muda, $\quad$ P. \\
\hline Estás diciendo una palabra inmensa. & Estás diciendo una palabra inmensa. \\
\hline Doliente. Absorta. Pálida. & Doliente. Absorta. Pálida. \\
\hline Un racimo de sol & Un racimo de sol \\
\hline Me dice adiós desde tu vestido oscuro. & Me dice adiós desde tu vestido oscuro. \\
\hline Detrás de ti se aleja & Detrás de ti se aleja \\
\hline La hélice infinita del crepúsculo. & La hélice infinita del crepúsculo. \\
\hline & $\begin{array}{l}\text { Muda mi amiga, } \\
\text { Sola en lo solitario } \\
\text { Grandiosa y fecunda } \\
\text { Magnética esclava } \\
\text { Sucumben susflores } \\
\text { Y Ulena } \\
\text { Es de } \\
\text { Tristeza } \\
\text { P. }\end{array}$ \\
\hline
\end{tabular}

Poema 2 de 1924, con las anotaciones manuscritas incorporadas.

La luz te envuelve

En su llama mortal

Pálida doliente. Seria. Absorta

Así situada

Contra las

Viejas hélices

Del crepúsculo

Detrás de ti da vueltas

El carroussel de las estrellas.

Doliente. Absorta. Muda,

Estás diciendo una palabra inmensa.

Doliente. Absorta. Pálida.

Un racimo de sol

Me dice adiós des de tu vestido oscuro.

Detrás de ti se aleja

La hélice infinita del crepúsculo.

Muda mi amiga,

Sola en lo solitario

Grandiosa y fecunda

Magnética esclava

Sucumben sus flores

Y llena es de tristeza.
Poema 2, Veinte Poemas de Amor y una Canción Desesperada, Nascimento, 2o Edición, 1932

En su llama mortal la luz te envuelve.

Absorta, pálida doliente, asi situada

Contra las viejas hélices del crepúsculo

Que en torno a ti da vueltas.

Muda, mi amiga,

Sola en lo solitario de esta hora de muertes

Y llena de las vidas del fuego,

Pura heredera del día destruido.

Del sol cae un racimo en tu vestido oscuro.

De la noche las grandes raíces

Crecen de súbito desde tu alma,

$\mathrm{Y}$ a lo exterior regresan las cosas en ti ocultas,

De modo que un pueblo pálido y azul

De ti recién nacido se alimenta.

Oh grandiosa y fecunda y magnética esclava

Del círculo que en negro y dorado sucede:

Erguida, trata y logra una creación tan viva

Que sucumben sus flores, y llena es de tristeza. 
II. CARTA DE PABLO NERUDA PARA FRANCISCO CUEVAS MACKENNA Y PAULINA, REMITIENDO ORIGINALES INÉDITOS DE "EL GRAN OCÉANO" (HACE 60 AÑOS)

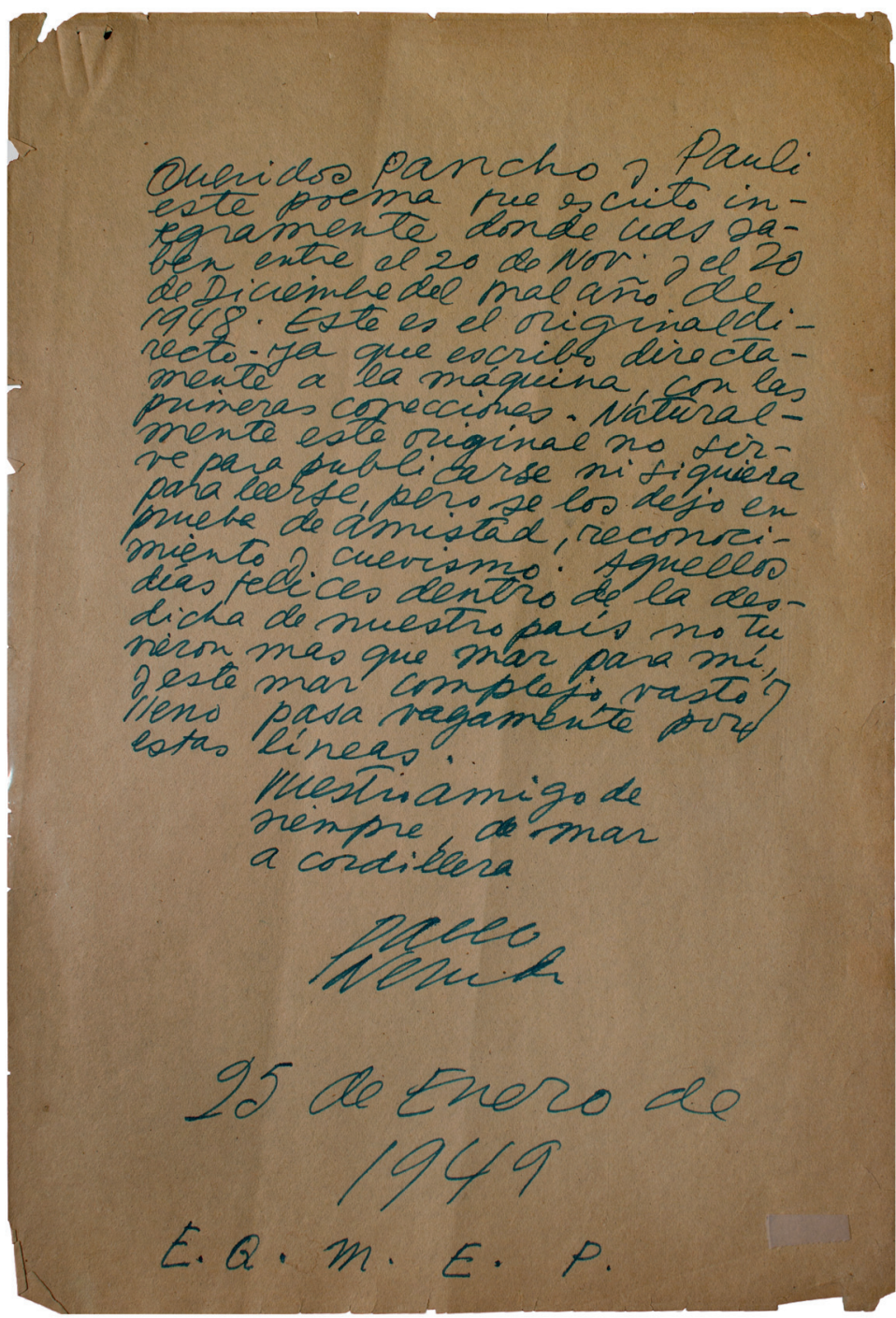

Carta manuscrita dirigida a Pancho y Paulina, de fecha 25.01.49. Una página, escrita en tinta verde. Parte final: “E.Q.M.E.P”. Misteriosas iniciales que en Antología General, se aventura descifrar 
En página 555 de la Antología General de Pablo Neruda, edición conmemorativa de la Real Academia Española y la Asociación de Academias de la Lengua Española, año 2010, World Color Perú S.A., aparece la fotografía que antecede, que es un manuscrito remisor de los originales de "El Gran Océano", escrito directamente a la máquina y con sus primeras correcciones, por el propio Pablo Neruda (algunas en tinta azul son de Hormiguita). En la página 554 se explica que ésta es la carta manuscrita que acompaña la remesa de "El Gran Océano" y se hace una breve referencia, pero a continuación todo está referido a la transcripción de las 20 páginas de La Crónica de San Pancho, que es un inédito muy completo en que Neruda, también lúdicamente, hace un juego de agradecimiento hacia Francisco Cuevas Mackenna y que no tiene una relación directa con "El Gran Océano", quizás el más importante poema, capítulo XIV del Canto General. He escogido esta pieza no solo por el valor intrínseco de ella, sino porque constituye una clara expresión de un reconocimiento a la amistad, entregando lo que para él fue siempre un tesoro, la palabra escrita, su palabra escrita. Es una forma indicativa notable de un autorreconocimiento, de una autoaceptación que trae desde la infancia y que no lo abandonó jamás. Es, al mismo tiempo, sinónimo de la confianza absoluta en sí mismo, en sus valores y también un reconocimiento a la trascendencia que su obra podría tener (más bien, debía alcanzar necesariamente). Un simple papel ordinario, una hoja de roneo, con su letra caligráficamente dibujada, usando su característica tinta verde, cuando todavía no era un personaje reconocido al grado en que logró serlo en los años siguientes, él tenía su círculo de amistades, en que no existían los privilegios, sino, a la manera provinciana, en que los valores son básicos y funcionan al ritmo de la solidaridad. Estamos refiriéndonos a un hecho ocurrido a fines de enero de 1949, a solo unos días de la fuga del país a través de la baja Cordillera de Los Andes, en el extremo sur. Treinta años después, el 22.4.1978, "con mucho cariño", entregaron Panchote y Patricia este legajo que contenía todos los poemas que conforman "El Gran Océano", que es el capítulo XIV del Canto General, escrito por Neruda entre el 20 de noviembre y el 20 de diciembre de 1948, en S.P. (Sanpancho).

Se reproducen a continuación dos poemas originales de "El Gran Océano" y "La Ola", equivalente al poema 12 , con sus correcciones originales en tinta verde de Neruda y en tinta azul o lápiz grafito, correcciones que aparecen todas, salvo excepciones, en la edición del Canto General de América, Imprenta Juárez, de 1950, $3^{\text {a }}$ edición clandestina. También en la de Losada de 1968, como por ejemplo, correcciones que forman la "piel desnuda del planeta" en circunstancias que el original corregido dice "forman la piel florida del planeta", al igual que el reemplazo de "ovas" por "uvas" en el verso de la edición de América de 1950. Esto significa que las correcciones fueron respetadas por el impresor, salvo en cuanto al orden de ciertos versos. Termina este conjunto de manuscritos el " 14 de Diciembre 1048.- Sanpancho". 


\section{El Gran Océano. Poema I}

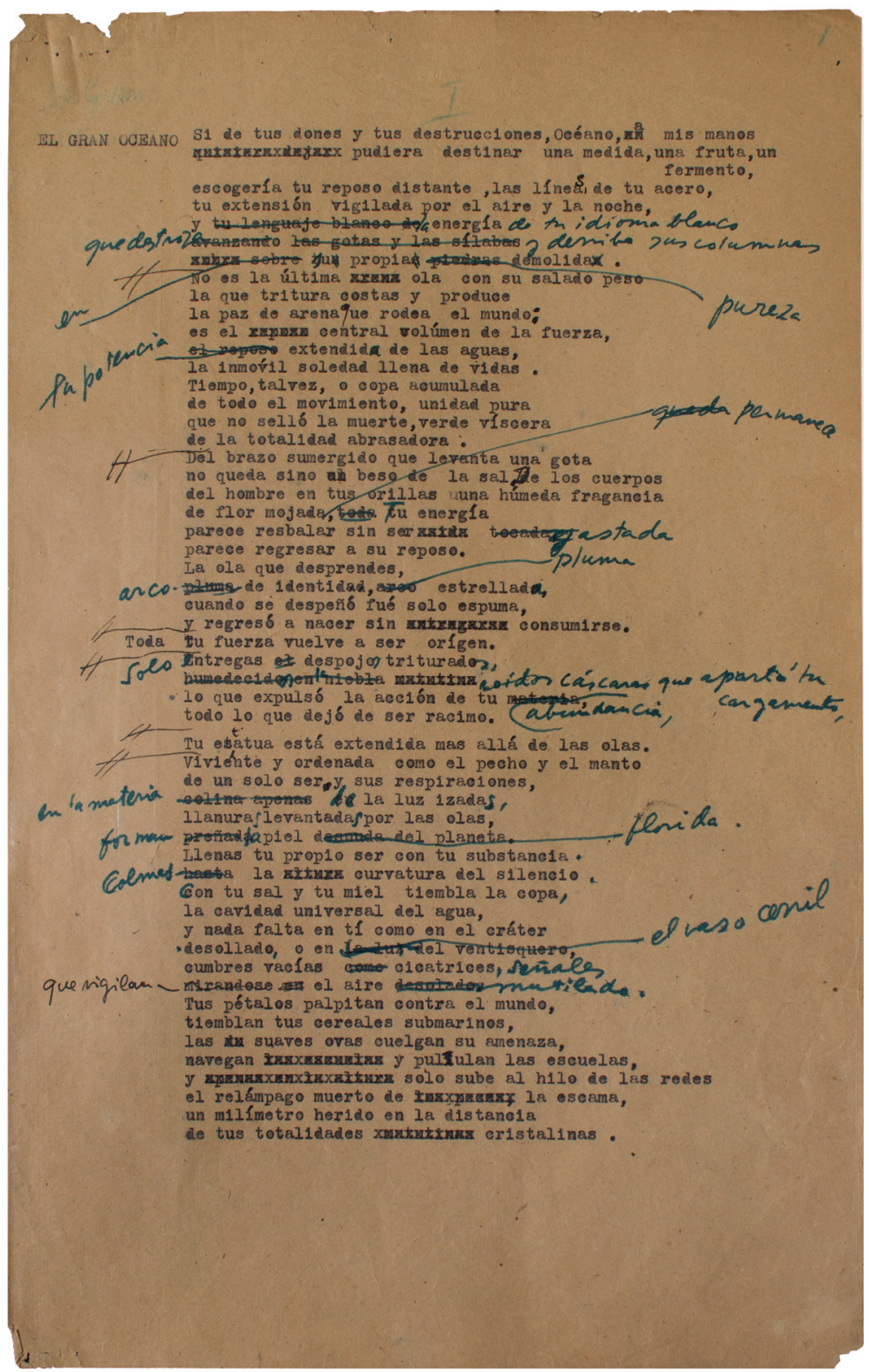


La Ola. Poema XII

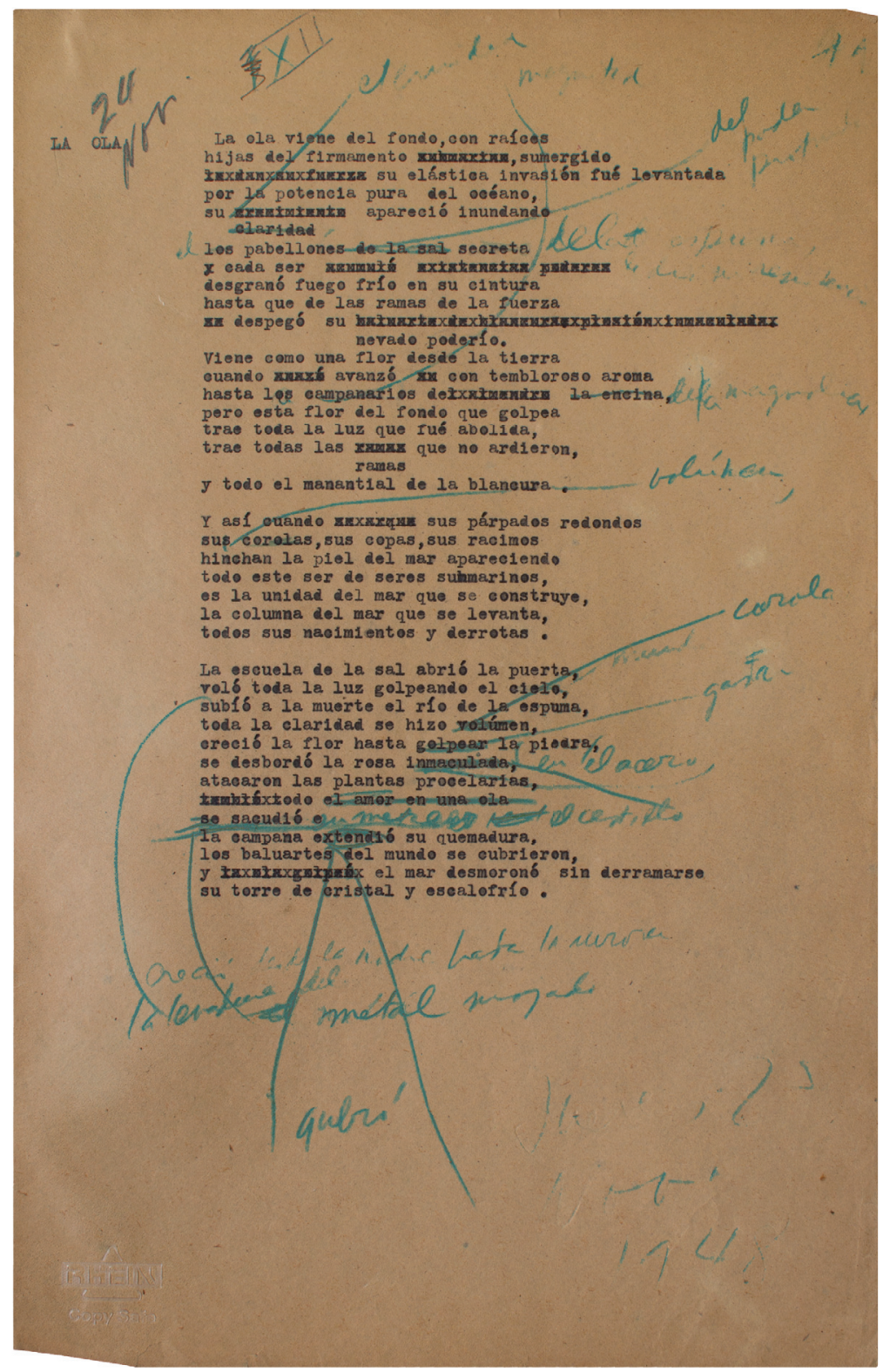


III. “CASTRO ALVES DEL BRASIL”

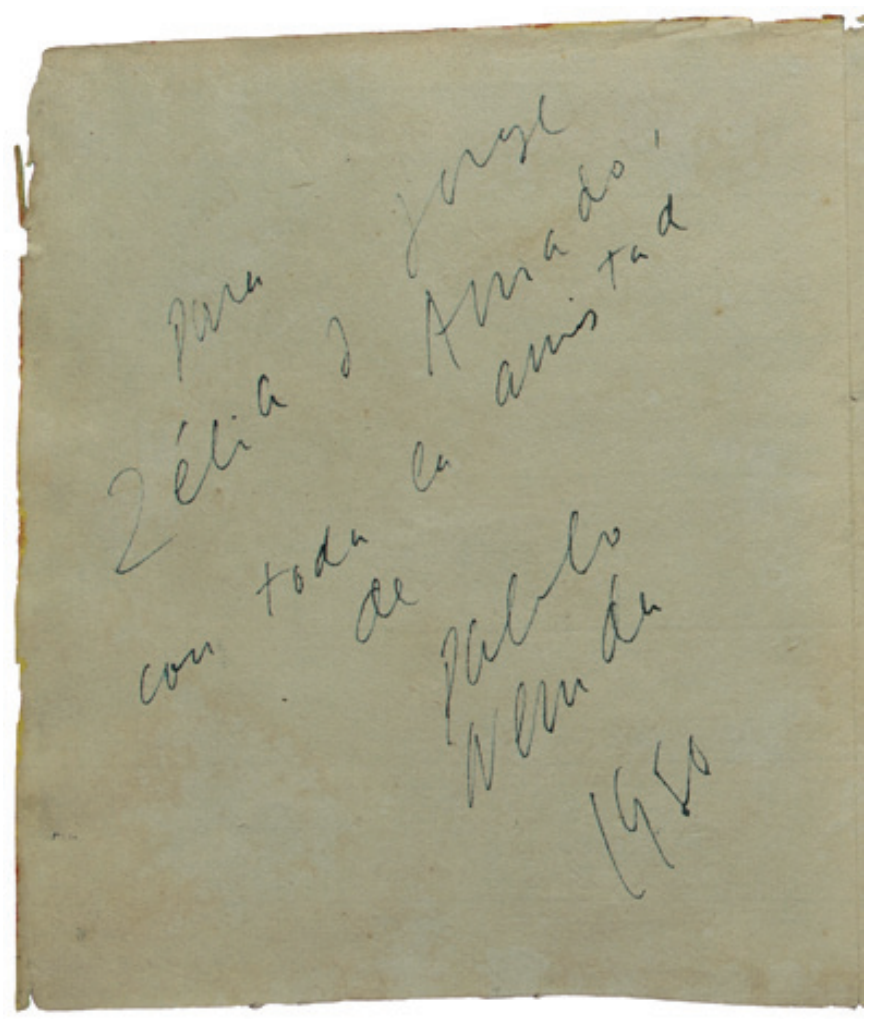

Dedicatoria del manuscrito "Castro Alves del Brasil"

Para el final he dejado un anuncio: apareció un original de un poema de Los Libertadores. Es un original extraordinario, fechado "Dobris, 12 de diciembre de 1950" (hoy República Checa), con una dedicatoria que va arriba. Es el original sin ninguna corrección, pero incompleto, pues faltan las estrofas cuarta, quinta y sexta. Se publicó en la edición de 1968 de Losada, completo, con una nota que reenvía a la primera edición de las Obras Completas de Losada, en un tomo, 1956, publicado por primera vez, aunque en la de 1968, por decisión del editor, es incluida en Los Libertadores, "lugar que le corresponde por su tema". Hemos de entender que éste es un pre-original o es un duplicado, pues el "original original" se supone en Oxford, poseedor del resto de los originales de Los Libertadores del Canto General, a cuya colección solo faltaría el original de "Morazán". Está dedicado a Jorge Amado, notable escritor brasileño, y a Zélia, su mujer, grandes amigos de siempre. 